\title{
Montage in Russian Imaginism: Poetry, theatre and theory
}

\author{
Tomi Huttunen \\ Department of Modern Languages \\ University of Helsinki , P. O. Box 24 (Unionkatu 40B) \\ 00014 Helsinki, Finland \\ e-mail: tomi.huttunen@helsinki.fi
}

\begin{abstract}
The article discusses the concept of montage as used by the Russian Imaginist poetic group: the montage principle in their poetry, theoretical writings and theatre articles. The leading Imaginist figures Vadim Shershenevich and Anatolij Mariengof were active both in theorizing and practising montage in their oeuvre at the beginning of the 1920s. Shershenevich's application of the principle in poetry was called "image catalogue", a radical poetic experiment in the spirit of both Walt Whitman and Sergei Eisenstein. Mariengof's main contribution to the montage poetics was his first fictional novel The Cynics (1928). The article also discusses the Imaginists' writings on the essence of theatre as an autonomous art form - Shershenevich's actitivy in the OGT (Experimental Heroic Theatre) and Mariengof's participation in the work of the MKT (Moscow Kamerny Theatre).
\end{abstract}

Keywords: Russian Imaginism, avant-garde poetry, experimental theatre, montage, metro-rhythm

The poetry and theoretical writings of the Russian Imaginists are of growing interest among Russian literary historians today. ${ }^{1}$ The Moscow Imaginist group was active during the years 1918-1924, although the group dissolved only in 1928. The poets of the group - including Anatolij Mariengof, Vadim Shershenevich, Sergej Esenin, Ryurik Ivnev, Ivan Gruzinov, Aleksandr Kusikov and others - are, apart from

\footnotetext{
1 The text has been written as part of the University of Helsinki research project "Autogenetic Russian Avant-garde" (Kone Foundation) and the Finnish Centre of Excellence "Choices of Russian Modernisation" (Academy of Finland).
} 
Esenin, still rarely acknowledged as having written anything except controversial memoirs about their bohemian hooligan years. Yet the Russian Imaginists were also active in experimenting with poetic language and formed an example for several minor schools of poetry (such as the Petrograd group of Imaginists, the Nichevoks, the Expressionists, and even the Oberiuts) in a way that is well worth of studying further.

The role of Imaginism in Russian culture is being reconsidered at the moment, as Anatolij Mariengof's Collected Works (Mariengof 2013, in three volumes) has seen the daylight, and the Imaginist epatáge, performances and happenings are already being discussed as part of the "everyday life theatre" and "street art" of the 1920s avant-garde culture. However, for some reason, the study of Imaginist poetics is paid little attention in the works of Russian scholars. Also the question of the Imaginists in the theatre has too often been neglected.

The question of cinematic montage has been studied (even recently) in connection with Anglo-American Imagists, in the works of Ezra Pound, T. E. Hulme, T. S. Eliot, or Hilda Doolittle (see McCabe 2005: 18-55; Edmunds 1983: 36-45; Connor 2004; Iser 1966: 361-393; Kong 2005). Therefore the question of montage in Russian Imaginism logically arises, and needs to be addressed for a proper understanding of the montage principle in Modernist poetry. In this article I shall concentrate, on the one hand, on the Imaginists' ideas that can be related with the general montage principle in culture, with Sergei Eisenstein's view of montage as something typical of any artistic juxtaposition. On the other hand, I shall discuss the Imaginists' own use of the concept of montage, which appears only in their articles on experimental theatre of the early 1920s.

In their poetry and manifestos, the Imaginists proclaimed that the Image in poetry is an end in itself. According to them, the core of poetry was the interplay between individual images. The Imaginists' poetic experiments include Sergej Esenin's Dadaist idea of the "image machine", Vadim Shershenevich's radical genre of the "image catalogue", and Anatolij Mariengof's conflictual images that create "image chains", and, eventually, his montage novel The Cynics (1928), which in a way synthesizes the above-mentioned Imaginist experiments with montage poetics. Esenin worked on his principle of the "image machine" already in the late 1910s, Shershenevich's programmatic montage poem "Image catalogue" was written in 1919, and Mariengof's Imaginist montage novel The Cynics was published in 1928, when the poetic school had already ceased to exist.

The most technical example of Imaginist montage poetics can be found in Esenin's rare avant-gardist ideas. His experiments with the "image machine" did not leave any significant poetic traces in his Collected Works, and we only know about these experiments from the memoirs of his contemporaries. Usually, Esenin did not engage himself in theoretical issues; in this he differs from his colleagues 
Mariengof and Shershenevich. For him, Imaginism had to do with the organic nature of the Russian language; for him, any writer who had the talent to create expressive poetic images, was an Imaginist. Obviously influenced by the Dadaists, Esenin wanted to create a mechanism for arbitrary combinations between words. By picking up a pair of words from a newspaper, for example, a poet could create an astonishing, surprising image, and the poem would consist of these newly born images. What is of relevance here from the point of view of montage, is the emphasis on the reader's ability to combine the juxtaposed words.

According to the Imaginist Shershenevich, the verb, the predication, became unnecessary in poetry. He claimed that the metaphor in poetry is self-oriented, and that the metaphoric nature of the Russian language can be best expressed by using nouns. As a result he ended up omitting verbs in the poetic syntax. Nominative poetry and infinitive writing represent the most radical experiments in Shershenevich, as well as in Imaginism. We can only read Shershenevich's "Image catalogue" (1919) by trying to make up the predication, fitting verbs between the nouns in order to arrive at a unified, complete thought. This is the core of montage poetry: the reader should reconstruct the causal connections between the images and is forced to guess the missing verbs, and finally becomes the co-creator of the montage text.

This programmatic poem was a part of Shershenevich's poetic manifesto, his collection titled Horse as a Horse (1919), in which he applied his theoretical thinking to his own poetry. In his theoretical book $2 \times 2=5$ (1920) he had declared that the verb is the appendix of poetry, a disease of speech. The "Image catalogue" was a text with omitted verbs, while the poet has used clear omissions, pronouns, ellipses, instrumental nouns or inversion with a genitive construction to replace the verbs. Montage of nouns. Both the half-prosaic urbanism and the catalogue structure of the poem referred to Walt Whitman, who has also been related with the cinematic rhetorics of the early 20th century (see Timenchik 1982: 136; Yampolsky 1992: 151-152). In 1919, when Shershenevich's poem was written, he became very fond of Whitman - probably due to Korney Chukovsky's book The Poet-Anarchist Walt Whitman (1919) that definitely belonged to Esenin's library. In Whitman's search for Adamic language it is possible to see a kind of starting point for both Esenin's technical montage machine and Shershenevich's image catalogue. In the catalogue, the reader is supposed to reconstruct the interconnections between the words, which appear to be polyvalent significatory elements carrying semantic potential in themselves. The reconstruction (signification) is being done via predication (cf. Eisenstein 1964-1971, vol. 2: 285). There are certainly many things in common between Shershenevich and Eisenstein, whose ideas about the Chinese (or Japanese) ideograms are also apparent in Imaginist thinking of Shershenevich, Ivan Gruzinov and Ippolit Sokolov. 
Mariengof's most relevant contribution to the question of Imaginist montage was his fragmentary novel The Cynics ("Tsiniki", 1928), which I have discussed elsewhere (see Huttunen 2000; 2006; 2007). He had already underlined the active role of the reader in his theoretical article "The island of Buyan" (Buyan-Ostrov", 1920) in which he claimed that the main goal of a poet is to create a maximum of inner tension in the reader's mind. In an Imaginist text this is best achieved by a constant collisional juxtaposition of "pure" ("chistoe") and "impure" ("nechistoe"). The author chooses the most shocking juxtapositions for metaphors in order to force the reader to participate in a reconstructive process of generating synthetic meanings. This Imaginist principle is clearly seen in the metaphors used in The Cynics. In the mind of the narrator, nothing pure is expressed without its constant juxtaposition with something impure: love, for instance, is juxtaposed with constipation and enemas, flowers with cut-off heads, sentimental episodes with detailed descriptions of hygienic problems, etc. Also Shershenevich's "image catalogue" may be regarded as a dominant compositional device in The Cynics.

The Cynics is the story of two "ex-people", an unemployed historian Vladimir and his lover Olga, during the revolutionary years. It is a montage novel, and it can be treated as a collection of heterogeneous, apparently disparate and unrelated fragments. It is written as the first-person narrator Vladimir's fragmentary diary from the years 1918-1924. Vladimir is a historian, so the diary consists of his own numbered notes, contemporary news items and historical documents. The narrator demonstrates the method in an entry from 1922:

\section{1}

In the autumn of 1921 my fingers began to itch once again. Tattered scraps of paper appeared on my writing desk and sharp little black points appeared on my pencils. Each morning I fully intended to buy a notebook, and each evening I fully intended to apply my mind. But then I was beset by laziness, and I am not by habit so gauche as to resist the advances of such a charming creature.

The soft sheets of paper containing my 'drafts' were impaled on the spike in the 'thinker's cell', the hard sheets were preserved. I am grateful to Olga for her squeamishness.

Since I always forget to write the day of the week and the date, I am obliged to present them in chronological disorder. (Mariengof 1991: 67-68)

The "chronological disorder" described by the narrator is the core of the montage technique used by Mariengof in his first fictional novel. As any element in a montage text (and in an Imaginist "image catalogue"), the novel's fragments, when viewed 
in isolation, may be defined as relatively autonomous and polyvalent, carrying a semantic potential. This potential can be actualized only in juxtaposition with other elements. In the actual text, which according to Eisensteinian interpretation is a result of communication between the author's fragmentation and the reader's (re)integration, these elements often turn out to be multifunctional, and capable of generating new meanings on different levels of the text. In Shershenevich's Imaginist jargon, these elements are characterized as "pregnant word-images", meaning nouns bearing in themselves the potential image. The same concerns the seemingly disparate fragments of Mariengof's novel. Their actual meaning depends on discrete juxtapositions or non-discrete combinations with other fragments.

The narrative nature of the relatively autonomous fragments and descriptive passages in The Cynics is also related to the poetics of heteroaccentual rhyming, which was typical of Mariengof in his Imaginist poetry. In his poems, Mariengof often uses complex heteroaccentual rhyming, with the rhyming pair being separated by an irregular number of lines. For the reader, this presents the intriguing challenge of reconstructing the causality of the text. The heteroaccentual rhyme is one of the main features of Mariengof's poetics, rather than just a random experiment (Markov 1983). From the point of view of textual orchestration, the focus here is on the memory of the text and on the long-distance connection between textual segments. Also - and this is of relevance for an Imaginist as a visual thinker - the heteroaccentual rhymes are, as described by Mikhail Gasparov, "rhymes only for the eye" ("rifmy dlya glaz"; Gasparov 1993: 56). The Imaginists straightforwardly opposed any musicality in poetry. In The Cynics the repetition of certain motif-like descriptions or metaphors creates several intextual narratives within the novel. The most evident examples are the descriptions of the characters. In fact, all characters are described analogously, in terms of the cinematic montage principle. This is achieved with the help of metonymic narration and significant details, while the reader is left with the task of formation of the character, which appears to be a narrative text within a text. Every character is given a dominant detail (a close up), upon which his or her image is based, and which conveys the narrator's attitude towards the character.

However, Imaginist montage does not only appear in their poetry or prose: in fact, the only occasions on which the Imaginists themselves use the term montage appear in their articles devoted to the principles of the theatre as an autonomous art form. In the early 1920s the Imaginists were very active in the theatre. ${ }^{2}$ In 1920 Shershenevich began working at the Moscow Kamerny Theatre as the head of the literary section. Between 1921 and 1924 he also published over 120

2 For a more detailed treatment of the Imaginists' activity in theatre, see Huttunen, Salo 2010. The theatre part of this study is based on the joint project with Elli Salo. 
articles in theatre journals. Together with the actor and director Boris Ferdinandov they founded a theatrical laboratory called the "Experimental Heroic Theatre" ("Opytno-geroicheskij teatr"). It served as a platform for exploring the laws and rules of drama with quasi-scientific experiments. Originally the OGT was an independent theatre, but in 1922 they began working under the aegis of the Academy of Theatre (GITIS) in co-operation with such well-known directors as Vsevolod Meierhold, Nikolaj Foregger, and Lev Kuleshov and his collective.

Shershenevich and Ferdinandov with their OGT were against the intuitive and improvised forms of expression typical of the Kamerny Theatre. They were looking for the opposite - a scientific approach to theatre. In the spirit of Russian Formalism, Shershenevich and Ferdinandov were searching for theatre language's independent features, which is why they emphasized the notion of "differentiation", referring to theatre's artistic autonomy. Shershenevich had mentioned this notion already in his "Declaration of the Futurist theatre", written as early as 1914: "Imperatively: all arts are independent and cannot depend on one another [... the actor in contemporary theatre is a soldier wearing a shining uniform, but lacking the most important feature of a soldier - the possibility to be the hero of the battle" (Shershenevich 1916: 56-57; trans. mine - TH).

As to the idea of differentiation, Shershenevich's ideas sound rather similar to those of the philosopher-phenomenologist and semiotician Gustav Shpet, who had been close to the group of the Imaginists in the early 1920s (see Tihanov 2008: 268-270). Shpet theorized the principle of differentiation in his articles "On the differentiation of theatre performance" (1921) and "Theatre as art" (1922). He was against the Symbolists' striving for synthesis and defended the functional differentiation of the actors participating in the stage act. As Galin Tihanov (2008: 277) has shown, Shpet was promoting realistic theatre against the avant-garde. According to him, an actor was an artistic realization of creative work, since the eloquence of acting represented the substance of theatre as art (Shpet 1988: 52). Mimicry, gesticulation and movements should not be understood as interpretation, i.e. something secondary in relation to the "authorial" idea of the playwright or the director. The most important section is the stage act, while the actor's body remains the main element in theatre, since, in Shpet's view, it combines creativity and the material of the drama.

Shershenevich and Ferdinandov were trying to advance the language of the autonomous art of theatre, but, apart from that, the art of acting was one of the dominants in their theoretical writings as well. Their main impact on theatrical theory and methodology of acting was the principle called "metro-rhythm" (metroritm, sometimes ritmo-metr). This vehicle was supposed to reveal the hidden laws of theatre and expose them in the practises of the work of the actor. They believed 
that the principal regularity of a theatre play is dependent on the interrelation between metrics and rhythmics, on their mutual laws (Shershenevich 1922c). Thus, paradoxically, in their search for the autonomy of the theatrical language they relied either on musical terminology, or literary theory, i.e. on the structural principles of poetic language. Their definition of metro-rhythm could also be understood as an attempt to define theatrical chronotope, since metrics must naturally be understood as a spatial category, while rhythmics represents temporality. According to Shershenevich and Ferdinandov theatre is a thoroughly dynamic art form, and these dynamics emerge from the tension between temporal (rhythmical) and spatial (metrical) expressions. By defining the metrical and rhythmical elements in theatre - its metro-rhythmic essence - it becomes possible to perceive the regularity and mechanics of this art, to control the dynamics on stage (Ferdinandov 1922b). This logic leads us to another paradox in the writings of the OGT fellows: while searching for the autonomous language of experimental theatre, Shershenevich and Ferdinandov ended up asking what are the scientifically defined laws of theatre language and what is the basis for its predictable regularity. Avant-gardist features of unpredictability and unexpectedness are definitely distant from the OGT's metro-rhythmic theory.

According to the OGT theorists, the main element of theatre - the art of acting - has to be split into three kinetic parts: the voice movement, the physical movement and the emotional movement. Metro-rhythmical acting is based on the definition of these three movements as well as their simultaneous implementation. Ferdinandov (1922b) says that each part of the actor's work has to be organized in a metro-rhythmical shape, which allows the rotation of accentuated, non-accentuated, metrical and rhythmical features. Apart from the metro-rhythmical shape, the tonal level should also be defined in analysing the actor's movements. This way the dynamics of acting can be controlled, and it is possible to create regulated harmony for the theatre piece.

Metro-rhythmically arranged elements - text, music, decoration and technique - together with the art of acting create theatrical montage (Ferdinandov 1922b). In this context, the notion is somewhat surprising, yet understandable. The director Lev Kuleshov - working close to the OGT - has discussed montage in film in 1920 and made his famous conclusions about the reception effect of the organization of the film material. It is also worth noting that Kuleshov considered Ferdinandov as one of his teachers (see Kuleshov, Hohlova 1975: 68-69; Yampolsky 1991: 45-46). Thus the fashionable notion of montage was "in the air" in 1922, and in the following year Sergei Eisenstein would write his famous manifesto "Montage of attractions" ("Montazh attraktsionov", 1923). In their theoretical writings the Imaginists Shershenevich, Mariengof and Esenin, each in his own 
way, had discussed montage poetry. However, none of them had used the term itself. It appears in the Imaginists' vocabulary only in the theatrical articles after 1922.

The main idea of metro-rhythmical acting was that the actor is capable of translating the play (the text) into his/her body language, into gestures and movements. In the OGT the movements and emotions were subordinated to the word when reworking a previously existing dramatic text for stage. However, the complete stage performance was subordinated only to metro-rhythms. Montage was used as a word to emphasize the technical and scientific basis of metro-rhythm: with the help of techno-mechanical montage the biophysical element (the actor's body) became a regular element for the stage work rather than an arbitrary part of the play.

Within the theory of metro-rhythm Shershenevich concentrated on the form of the word and the role of the text in theatre. According to him, the theatrical word radically differs from literature's poetic word. In the OGT's experiments words were organized in a metro-rhythmic form as any other element of acting. The words would lose their lexical meaning and turn into phonemes. The most radical example of this was the Imaginist Nikolay Erdman's play Revolutionary Mystery, where the play consisted of arbitrary phonemes with no semantic basis what so ever. Erdman's play was written in an inconceivable language (vnesmyslovyi jazyk) in the spirit of the Futurists' transrational language (zaumnyi jazyk). Unfortunately, the play was never actually performed at the OGT (see Ivanov 1996: 229).

Shershenevich tried to realize his theory of theatrical word in the OGT's performances. The first public performances of their laboratory - Oedipus Rex (1921) and The Thunderstorm (1921) - were considered as research projects dedicated to the metro-rhythmical word. In these performances the actors were practically standing still and produced mere recitatives (see Miljakh 1998: 100). The OGT used texts by various playwrights, and Shershenevich revised many of them proceeding from his own theory. The OGT's last staged performance was his own The Lady with a Black Glove ("Dama v chernoj perchatke", 1922). It was the first and the last theatre text in the history of Russian theatre, which was constructed entirely according to the principles of metro-rhythm. Shershenevich did not ever continue developing the metro-rhythmical theatrical word after that.

The Imaginist Mariengof also worked at the Kamerny Theatre, mainly as a playwright. During that time he published plays Conspiracy of the Fools ("Zagovor durakov", 1922) and Babylon's Lawyer ("Vavilonskij advokat", 1924). Excerpts from the first play were published in the Imaginist poetic anthology Horse Garden ("Konskij sad") in 1921, which contained also Esenin's play Pugachev and Shershenevich's play One Enormous Insanity ("Odna sploshnaya nelepost"). In fact, director Meyerkhold was planning to stage all these plays in his own theatre (see Shershenevich 1922b). In 1923-1924 Mariengof collaborated actively with the 
director Alexander Tairov and kept writing articles for the Kamerny Theatre's own journal 7 Days of the MKT ("7 dnej MKT"). The Imaginists' own journal The Inn for Travellers in the Beautiful ("Gostinitsa dlya puteshestvuyuschih v prekrasnom", 1922-24) included several Mariengof's articles dedicated to theatre as well.

After the Imaginists' plays had been published, Shershenevich and Mariengof drifted into a serious dispute about the dramatic nature of these texts. This happened on the pages of the journal Theatrical Moscow in 1922. Shershenevich claimed that Mariengof's Conspiracy of the Fools was almost impossible to stage. The supremacy of the lyrical, which resulted from the play's poetic form and its Imaginist specifics, prevented the text from becoming on-stage action. Shershenevich accused Mariengof of writing a play of static poetic words without any metro-rhythmical dynamics: "Lots of movement without regularly working action" (Shershenevich 1922d). The play was mere declamation, he said, - a recitative in costumes. Mariengof answered by arguing that, in his opinion, the poetic and theatrical words do not differ significantly. They play according to the same rules, whereas "declamatory word is the essence of real theatre" (Mariengof 1922). In his later articles Mariengof (1922b, 1924) would also emphasize the indisputable dominance of the text in theatre. For him the playwright was the main subject in the art of theatre.

During this dispute Shershenevich had a possibility to advance and improve his theory of theatrical word. He would now argue that in literature in general the word was static by nature, while in theatre it was originally dynamic (Shershenevich 1922e). In Shershenevich's view, the theatrical word is not an end in itself, its semantics or poetic form was of relatively little importance. The reason for this is that the word's function is revealed only within the verbal montage, whose dynamicity belongs to the stage act. Thus the word becomes a part of a greater whole - a part of theatrical montage. A play as a written text represented verbal montage, which acquires its eventual significance only in theatrical montage, i.e. as part of the stage act with all its metro-rhythmically organized elements. It seems obvious that Shershenevich's theory of theatrical montage is, on the one hand, based on Lev Kuleshov's cinematic terminology, and, on the other hand, draws on the Imaginists' montage poetry ("image catalogues"). The theatrical word represents montage, because it is inseparable from the scientifically organized and technically realized stage action - for Shershenevich, the metro-rhythmical regularity of theatre concerns, apart from the word, also staging, decorations, music, acting and all the other sections or segments of the theatrical performance as a whole. 


\section{References}

Connor, Rachel 2004. H. D. and the Image. Manchester, New York: Manchester University Press. Edmunds, Susan 1994. Out of Line. History, Psychoanalysis and Montage in H. D.'s Longer Poems. Stanford: Stanford University Press.

Eisenstein, Sergei 1964-1971. Izbrannye proizvedeniya v 6-i tomah. Moscow: Nauka.

Ferdinandov, Boris 1922. Teatr segodnya. In: O teatre. Tver: Tverskoe izdatel'stvo.

Gasparov, Mikhail 1993. Russkie stihi 1890-h-1925-go godov v kommentariyah. Moscow: Vysshaya shkola.

Huttunen, Tomi 2000. Ot "slovoobrazov" k "glavokadram": imazhinistskij montazh Anatolija Mariengofa. Sign Systems Studies 26: 181-198.

- 2007. Imazhinist Mariengof: Dendi. Montazh. Ciniki. Moscow: Novoe Literaturnoe Obozrenie.

- 2010. Imazhinisty i teatr: 1922 god. In: Lavrov, Aleksandr; Ospovat, Aleksandr; Timenchik, Roman (eds.), Ot slov k telu: Sbornik statej k 60-letiyu Yuriya Tsivyana. Moscow: Novoe Literaturnoe Obozrenie, 362-373.

Huttunen, Tomi; Salo, Elli 2011. Imaginistit teatterissa. In: Idäntutkimus 4: 3-11.

Iser, Wolfgang 1966. Image und Montage. Zur Bildkonzeption in der Imaginistischen Lyrik und in T. S. Eliot's Waste Land. In: Iser, Wolfgang (Hg.) Immanente Ästhetik. Ästhetische Reflexion. München: Wilhelm Fink, 361-393.

Ivanov, Vladislav V. 1996. Bunt marginala. Analiticheskij teatr Borisa Ferdinandova. In: Ivanov, Vladislav V. (ed.), Mnemozina: dokumenty i fakty iz istorii otechestvennogo teatra XX veka. Vyp. 1. Moskva: GITIS, 211-241.

Kong, Ying 2005. Cinematic techniques in modernist poetry. In: Literature/Film Quarterly 33(1): 81-87.

Kuleshov, Lev; Hohlova, Aleksandra 1975. 50 let v kino. Moscow: Iskusstvo.

Mariengof, Anatoly 1922a. Da, poety dlya teatra. Teatral'naya Moskva 37: 6-7.

- 1922b. Budushchee myortvogo avtora. Ermitazh 14: 7-8.

- 1924. Razgovor po dusham. 7 dnei MKT 16.

- 1991. Cynics. Glas. New Russian Writing 1: 8-114.

- 2013. Sobranie sochinenij v 3-h tomah. Moscow: Terra/Knigovek.

Markov, Vladimir 1983. V zashchitu raznoudarnoj rifmy. In: Eekman, Thomas Adam; Worth, Dean S. (eds.) Russian poetics. Columbus: Slavica, 235-252.

McCabe, Susan 2005. Cinematic Modernism: Modernist Poetry and Film. Cambridge: Cambridge University Press.

Miljakh, A. 1998. Metroritm Borisa Ferdinandova. Moskovskij nabljudatel', 1: 99.

Shershenevich, Vadim 1916. Zelenaya ulica. Statji i zametki ob iskusstve. Moscow: Pleyada.

- 1922a. Pochemu ya ushel iz Kamernoro teatra. Teatral'naya Moskva 28: 9-10.

- 1922b. Rul na pravo. Teatral'naya Moskva 31: 6-7.

- 1922c. Puti Opytno-geroicheskogo teatra. Teatr i studija 1-2: 43-47.

- 1922d. Poety dlya teatra. Teatral' naya Moskva 34: 8-9.

- 1922e. Dramaturgi. Teatral'naya Moskva 50: 5-6.

Shpet, Gustav 1988. Teatr kak iskusstvo. In: Stakhorskij, Sergej (ed.), Iz istorii sovetskoi nauki o teatre: 20-e gody. Moscow: GITIS, 31-55.

Tikhanov, Galin 2008. Multifariousness under duress: Gustav Shpet's scattered lives. Russian Literature 63(2-4): 259-292. 
Timenchik, Roman 1982. Stihoryad i kinoyazyk v russkoj kulture nachala XX veka. In: Isakov,

Sergej (ed.), Finitis duodecum lustris. Sbornik statej k 60-letiyu prof. Yu. M. Lotmana. Tartu, $136-139$.

Yampolsky, Mikhail 1991. Kuleshov's experiments and the new anthropology of the actor. In: Taylor, Richard; Christie, Ian (eds.) Inside the Film Factory: New Approaches to Russian and Soviet Cinema. London, New York: Routledge, 31-50.

- 1993. Pamyat Tireziya: intertekstual'nost' i kinematograf. Moscow: Ad Marginem.

\section{Монтаж в русском имажинизме: поэзия, театр и теория}

В этой статье мы обсужАаем понятие монтажа в употреблении русского имажинистского поэтического кружка, монтажный принцип в их поэзии, теоретических работах и статьях, посвященных театру. Ведущие имажинисты Вадим Шершеневич и Анатолий Мариенгоф были активны в теории и практике монтажа начала 1920-х годов. ГАавное применение монтажа в поэзии Шершеневича бымо его стихотворение “Каталог образов” (1919), радикальный поэтический эксперимент в Аухе У. Уйтмена и С. М. Эйзенштейна. В творчестве Мариенгофа соответствующую роль играет его первый художественный роман Циники (1928). В статье мы также преАставмяем имажинистские статьи, посвященные независимым признакам искусства театра - в первую очередь, это связано с Аеятельностью Шершеневича в Опытно-Героическом Театре и Мариенгофа Московском Камерном Театре.

\section{Montaaž vene imažinismis: luule, teater ja teooria}

Artiklis vaadeldakse montaaži kasutamist vene imažinistide ringis, kes kasutasid montaažiprintsiipi oma luules, teoreetilistes käsitlustes ja teatrile pühendatud artiklites. Juhtivad imažinistid Vadim Šeršenevitš ja Anatoli Marienhof osalesid aktiivselt montaažiteoorias ja -praktikas 1920ndate aastate alguses. Šeršenevitši montaažiprintsiipide rakendamise näiteks on tema luuletus "Näidiste kataloog" (1919) - radikaalne poeetiline eksperiment Whitmani ja Eisensteini vaimus. Marienhofi loomingus täidab samasugust rolli tema esimene romaan "Küünikud” (1928). Artiklis käsitleme ka imažinistide artikleid, mis arutlevad teatri kui autonoomse kunstiliigi olemuse üle. 